\title{
Tantangan dan Peluang Pendidikan Islam pada Era Milenial
}

\author{
Ahmad Husein Ritonga \& Fahmi Bafadhal \\ Pascasarjana UIN Sulthan Thaha Saifuddin Jambi \\ E-mail: husein_ritonga@yahoo.com
}

\begin{abstract}
The millennial era presents new challenges and opportunities in the field of education. Information technology is a marker. Post modern culture and information globalization interact and have been integrated in education. Even though the millennial era has had a positive impact, this era is also closely related to work ethic, ethics and moral issues. The ease of information and technology that gives birth to laziness, not thinking deeply, not down to earth or not caring about the environment, tend to want to be free, westernized, and sometimes violate ethics. This paper through the author's reflection on the literature relating to Islamic education, aims to unravel the challenges and opportunities of Islamic education in the millennial era. The opportunity for Islamic education based on the integralism spirit of education is increasingly greater to be the main choice of this millennial era education, even though the challenges that will be faced are also getting harder.
\end{abstract}

Keywords: millennial era; Islamic education.

\begin{abstract}
Abstrak: Era milenial memberi tantangan dan peluang baru dalam bidang pendidikan. Teknologi informatika menjadi penanda. Budaya post modern dan globalisasi informasi berinteraksi dan telah terintegrasi dalam pendidikan. Sekalipun era milenial memberi dampak positif, era ini juga erat dengan masalah etos kerja, etika dan moral. Kemudahan informasi dan teknologi yang ada melahirkan sifat malas, tidak berfikir mendalam, tidak membumi atau kurang peduli pada lingkungan, cenderung ingin bebas, kebarat-baratan, dan terkadang melanggar etika. Tulisan ini melalui refleksi penulis terhadap literatur yang berkaitan dengan pendidikan Islam, bertujuan mengurai tantangan dan peluang pendidikan Islam pada era milenial. Peluang pendidikan Islam berbasis spirit integralisme pendidikan semakin besar untuk menjadi pilihan utama pendidikan era milenial ini, sekalipun tantangan yang akan dihadapi juga semakin berat.
\end{abstract}

Kata-kata kunci: era milenial; pendidikan Islam.

\section{Pendahuluan}

Generasi muda saat ini disebut sebagai generasi milenial, mereka harus berhadapan dengan teknologi informatika yang membuka lebar pengaruh budaya barat yang selama ini masih dianggap tidak sesuai dengan budaya Islam dan kepribadian bangsa Indonesia. Rasulullah mengajarkan didiklah anak-anakmu sesuai dengan zamannya. Kalau mengenai generasi milenial ini harus siap menghadapi tantangannya, namun yang terpenting tetap kuat dengan karakter keIslaman dan keIndonesiaannya. 
Perkembangan zaman adalah sesuatu yang natural, yang tidak dapat dihambat laju perkembangannya. Mulai dari era kelasik, modern, post modern sampai pada era milenial. Oleh karenanya memasuki era millennial sesungguhnya ciri-ciri post modern dan ciri-ciri globalisasi sebagaimana dipahami masih melekat. Hal tersebut akan terasa berat jika berbagai tantangan dan permasalahan yang terdapat pada setiap zaman tersebut belum dapat dipecahkan, sehingga masalah dan tantangannya bertumpuk tumpuk. Namun, semua itu akan terasa ringan, jika masalah dan tantangan yang terdapat pada post modern dan globalisasi tersebut dapat diatasi, sehingga beban yang ada di pundak kita tidak terlalu berat.

Kesiapan ummat manusia dalam menghadapi permasalahan tersebut kondisinya berbeda-beda. Yakni ada yang kondisinya masih berat, yakni ketika ia belum dapat memecahkan masalah post modern dan globalisasi, sudah datang lagi masalah baru; ada yang sudah ringan, yakni kelompok yang sudah dapat menyelesaikan masalah post modern dan era globalisasi, dan tinggal menghadapi masalah era milenial.

Pendidikan Islam sebagaimana yang akan diuraikan pada tulisan ini akan menawarkan solusinya yang tepat. Selanjutnya terkait dengan permasalahan dan tantangan yang terjadi di era millennial antara lain terkait dengan adanya sikap dan perilaku manusia yang ciri-cirinya antara lain: (1) suka dengan kebebasan; (2) senang melakukan personalisasi; (3) mengandalkan kecepatan informasi yang instant (siap saji); (4) suka belajar; (5)bekerja dengan lingkungan inovatif, (6) aktif berkolaborasi, dan (7) hyper technology (8) critical, yakni terbiasa berfikir out of the box, kaya ide dan gagasan; (9) confidence, yakni mereka sangat percaya diri dan berani mengungkapkan pendapat tanpa ragu-ragu; (10) connected, yakni merupaka generasi yang pandai bersosialisasi, terutama dalam komunitas yang mereka ikuti; (11) berselancar di sosial media dan internet (12) sebagai akibat dari ketergantungan yang tinggi terhadap internet dan media sosial, mereka menjadi pribadi yang malas, tidak mendalam, tidak membumi, atau tidak bersosialisasi dilur komunitasnya; (13)cenderung lemah dalam nilai-nilai kebersamaan, kegotongroyongan, kehangatan lingkungan dan kurang kepedulian sosial; (14)cenderung bebas, kebarat-baratan dan tidak memperhatikan etik dan aturan formal, adat istiadat, serta tata krama. ${ }^{1}$

Dari sekian karakter masyarakat millennial itu, nampaknya terdapat beberapa poin yang terkait erat dengan etos kerja, etika dan moral, yakni malas, tidak mendalam, tidak membumi, kurang peduli pada lingkungan, cenderung bebas, kebarat-baratan, dan melanggar etika sebagaimana ditemukan butir 12, 13 dan 14 yang menyangkut dengan etos kerja, etika. Semua masalah etika dan moral inilah yang menjadi tanggung jawab pendidikan Islam. Itulah sebabnya Noory Okthariza mengatakan: dalam kaitannya dengan toleransi, satu-satunya penjelasan adalah pendidikan. Semakin tinggi tingkat pendidikan seseorang, kecenderungan dia untuk bersikap terbuka dan toleran akan semakin tinggi. Pendidikan yang baik

\footnotetext{
${ }^{1}$ Abuddin Nata, Pendidikan Islam di Era Milenial, Conciencia, Vol. 18, No. 1, 2018, hlm. 10-28.
} 
membuat seseorang makin bisa memilah danmencerna informasi secara akurat di tengah- tengah timbunan informasi pasa era digital. ${ }^{2}$

Era millineal dengan ciri-cirinya sebagaimana tersebut di atas pada ujungnya harus dihadapi dan dijawab oleh dunia pendidikan, sehubungan dengan kondisi ini, Mansour Fakih dalam pengantarnya terhadap terjemahan buku William F. O’Neil berjudul Ideologi-ideologi Pendidikan, menyatakan: para praktisi pendidikan seperti para guru ataupun dosen di lembaga pendidikan ataupun sekolah formal, pelatih (trainer) pada tempat kursus maupun loka karya atau bahkan para pemandu pelatihan (fasilitator) di berbagai arena pendidikan non formal ataupun pendidikan rakyat (popular education) di kalangan buruh, petani ataupun rakyat miskin, banyak yang tidak sadar bahwa ia tengah terlibat dalam suatu pergumulan politik dan ideologi melalui arena pendidikan. ${ }^{3}$

\section{Potensi Pendidikan Islam Menghadapi Era Millenial}

Terdapat sejumlah potensi yang dimiliki pendidikan Islam dalam menghadapi tantangan di era millennialyang ciri-ciri serta hubungannya dengan era sebelumnya telah dikemukakan di atas. Potensi yang dimiliki pendidikan Islam dalam menghadapi era millineal tersebut antara lain terkait dengan sifat karakter pendidikan Islam yang holistik, komprehensif, progresif dan responsive. Perhatian pendidikan Islam terhadap perbaikan karakter yang cukup besar, integralisme pendidikan Islam dalam penyiapan generasi unggul, contoh dan keteladanan yang diberikan oleh Rasulullah SAW dalam menjalani kehidupan dalam berbagai situasi dan kondisi, pengalaman pendidikan Islam dalam menyiapkan sumber daya manusia yang unggul, pengalaman pendidikan Islam dalam menyiapkan lulusan yang berjiwa entrepreneur. Berbagai potensi ajaran Islam tersebut dapat dikemukakan sebagai empat karakteristik pendidikan dalam Islam.

\section{Sifat dan Karakteristik Pendidikan Islam}

Pada dasarnya sifat dan karakter pendidikan Islam adalah sama dengan sifat dan karakteristik ajaran Islam, yaitu ajaran yang didasarkan pada teologi humanism teo-prophetik. Dengan teologi ini, maka ajaran Islam selain mendasarkan ajaranya pada ajaran Tuhan yang terdapat di dalam al-Qur;an, dan ajaran Nabi Muhammad SAW yang terdapat di dalam hadisnya (ucapan, perbuatan dan ketetapan), juga berdasarkan pendapat akal pikiran yang sehat yang tidak bertentangan dengan ajaran al-Qur'an dan al-Hadis. Dengan demikian, di samping memelihara, menjaga dan mengamalkan ajaran yang bersifat perenialis, juga yang bersifat temporer yang dihasilkan para ahli, tokoh agama, peneliti, cendekiawan melalui kajian, penelitian dan sebagainya. Denga cara demikian fleksibilitas dan akomadatif terhadap berbagai perkembangn baru yang timbul di era milleneal termasuk yang menjadi salah satu ciri ajaran Islam. Dengan demikian, hal-hal baru yang

\footnotetext{
2 Noory Okthariza, Generasi Milenial, Toleransi, dan Globalisasi, Kompas, 28 Desember 2017.

3 William F. O'neil, Ideologi-ideologi Pendidikan, penterj. Omi Intan Naomi, (Yogyakarta: Pustaka Pelajar, 2008). hlm. 10.
} 
dihasilkan era millennial yang sejalan dengan ajaran Islam dapat diterima. Sikap yang dinamis, inovatif, kreatif, dan berani keluar dari kebiasaan lama (out of the box) yang muncul di era millenial misalnya dapat diterima oleh ajaran Islam.

Di dalam al-Qur'an dan al-Hadis terdapat nama-nama yang baik bagi Allah (Asmaul Husna) yang menurut hadis riwayat Turmuzi, berjumlah 99 atau 100 misalnya ,dan kita diminta oleh Allah dan Rasul-Nya agar meniru sifat-sifat-Nya itu, misalnya sifat almushawwir: memembentuk atau merubah sehingga kedaannya berbeda dengan sebelumnya (dinamis), sifat-Nya al-khaliq: menciptakan sesutu yang baru yang tidak ada contoh sebelumnya(inovafif); sifat almubdiu: memulai sesuatu yang baru atas usaha dan keinginan sendiri (kreatif); dan sifat albaari: memberikan keleluasaan untuk melakukan sesuatu tanpa terikat pada contoh sebelumnya.

Selama ini, Asma al-Husna dipahami secara mistik, yakni dengan mengharapkan keberkahan, misalnya bahwa dengan membaca dan menghafalnya diharapkan memperoleh syafa'at (pertolongan). Tuhan di akhirat, atau agar dilapangkan dalam kuburnya dan sebagainya. Tentu saja sikap yang demikian tidak salah, dan boleh saja. Namun bersamaan dengan itu seharusnya pemahaman terhadap Asma al-Husna disertai dengan menangkap spirit atau etos kerja yang terdapat di dalamnya, sebagaimana yang telah diperlihatkan oleh Tuhan. Sifat dan karakteristik pendidikan Islam berikutnya terkait dengan pandangannya terhadap waktu, era atau zaman. Islam mengakui adanya waktu yang berbeda-beda, kondisi dan situasi yang ada di dalamnya serta pengaruhnya bagi kehidupan manusia.

Selanjutnya, al-Quran menyatakan bahwa waktu siang sebagai saat berusaha mencari rezeki dan waktu malam sebagai saat beristirahat. Hal ini dinyatakan dalam surat An-Naba, 78: 9-11: "Dan Kami jadikan tidurmu untuk istirahat; dan Kami jadikan malam sebagai pakaian; dan Kami jadikan siang untuk mencari penghidupan." Waktu malam dalam ayat tersebut diartikan pakaian, karena malam itu gelap menutupi jagat sebagaimana pakaian menutup tubuh manusia. ${ }^{4}$

Di sisi lain al-Quran secara seimbang mengemukakan bahwa Tuhan menggunakan waktu untuk menurunkan al-Quran, mewajibkan ibadah puasa, mengerjakan ibadah haji dalam untaian yang bersamaan. Melaksanakan shalat tahajjud, berusaha mencari rezeki, beristirahat dan sebagainya. Hal ini sejalan dengan kandungan surat al-Ashr, 103:1-3: 1. Demi masa; 2. Sesungguhnya manusia itu benar-benar dalam kerugian; 3. Kecuali orang-orang yang beriman dan mengerjakan amal saleh dan nasehat menasehati supaya mentaati kebenaran dan nasehat menasehati supaya menetapi kesabaran." Pada ayat tersebut al-ashr diartikan waktu, padahal sebenarnya kata al-ashr pada makna aslinya bukan waktu, tapi perasaan. Kata al-mu'shirat misalnya berarti perasan, seperti perasan buah-buahan, atau juz, seperti perasan buah jeruk, anggur,dan sebagainya. Penggunaan kata al-ashr untuk waktu dimasudkan agar waktu tersebut digunakan, atau dimanfaatkan dengan sebaik-baiknya, sebagaimana halnya buah-buahan yang inti dan sarinya diambil.

${ }^{4}$ Alquran Terjemah, (Jakarta: Departemen Agama RI, 2006), hlm.864. 


\section{Perbaikan Karakter Sebagai Tujuan Utama Pendidikan Islam}

Tanggung jawab pendidikan Islam dalam memberikan bimbingan pada manusia dalam menghadapi era millennial juga dapat dilihat dari perhatian pendidikan Islam terhadap perbaikan karakter. Mohammad Athiyah al-Abrasyi misalnya mengatakan: Pendidikan budi pekerti adalah jiwa dari pendidikan Islam, dan Islam telah menyimpulkan bahwa pendidikan budi pekerti dan akhlak adalah jiwa pendidikan Islam. Mencapai suatu akhlak yang sempurna adalah tjuan sebenarnya dari pendidikan Islam. Tapi ini tidak berarti bahwa kita tidak mementingkan pendidikan jasmani, akal atau ilmu ataupun segi-segi praktis lainnya. Tetapi hal tersebut berarti bahwa kita mesti memperhatikan segi-segi pendidikan akhlak seperti juga segi-segi lainnya. Anak-anak membutuhkan kekuatan jasmani, akal, ilmu dan mereka juga membutuhkan pula pendidikan budi pekerti, perasaan, kemauan, cita-rasa dan kepribadian. ${ }^{5}$

Dalam pendidikan Islam kosakata karakter biasanya disebut dengan akhlaq yang secara harfiah berarti perangai, tabi'at, prilaku, sikap, budi pekeri. Kata akhlak dekat dengan khalaq artinya penciptaan, dan dekat dengan kata makhluq yang berarti yang diciptakan. Hal ini menunjukkan bahwa akhlak merupakan hiasan bagi makhluk, atau sesuatu yang harus dilakukan oleh makhluk ciptaan Tuhan sebagai Khaliq (Maha Pencipta). Selanjutnya dari definisi akhlak yang dikemukakan Ibn Miskawaih dan al- Ghazali: yakni ekpresi jiwa yang muncul dengan mudah tanpa memerlukan pemikiran dan pertimbangan, dapat diketahui bahwa sesuatu dapat dikatakan akhlak apabila telah memiliki lima ciri, yaitu: sudah mendarah daging, sudah mudah dan gampang dilakukan; dilakukan atas kemauan sendiri; dilakukan dengan sebenarnya, dan diniatkan karena Allah SWT. ${ }^{6}$

Selanjutnya dengan mengacu pada surat al- Nahl, 16:78: "Dan Allah mengeluarkan kamu dari perut ibumu dalam keadaan tidak mengetahui sesuatupun, dan Dia memberi kamu pendengaran, penglihatan dan hati, agar kamu bersyukur." Kosakata al-sam'a atau pendengaran adalah representasi dari pancaindera. AlQur'an menggunakan kosatakata al-sam'a sebagai sampling dari pancaindera lainnya, karena di antara pancaindera yang lima, pendengaranlah yang pertama kali berfungsi, dan tepatnya tujuh jam setelah bayi dilahirkan, pendengaran sang bayi sudah berfungsi dengan baik, dan itulah sebabnya yang pertama kali dilakukan terhadap bayi adalah dengan memperdengarkan suara azan pada telinganya. Sedangkan kosa kata abshar yang terdapat pada potongan ayat tersebut dapat diartikan penglihatan, namun bukanlah penglihatan dengan mata kepala melainkan dengan akal pikiran. Dengan menggunakan pemikiran manusia dapat menentukan tentang yang baik dan buruk yang selanjutnya disebut dengan etika. Selanjutnya kosakata af-idah yang terdapat pada ayat tersebut dapat

5 Al-Abrasyi, Mohd. Athiyah, Dasar-dasar Pokok Pendidikan Islam, terj. A. Bustami Gani, (Jakarta: Bulan Bintang, 1970), hlm. 15.

${ }^{6}$ Abuddin Nata, Pendidikan Islam di Era Milenial, Conciencia, Vol. 18, No. 1, tahun 2018, hlm. 4-6. 
diartikan hati nurani yang selalu jujur dan lurus. Melalui hati inilah dapat ditentukan baik atau buruk yang selanjutnya dikenal dengan moral.

Islam menerima pendapat pancaindera, akal, dan hati nurani, maka ajaran Islam menerima adat istiadat, budi pekerti, budaya, etika dan moral dalam batasbatas yang sejalan dengan al-Qur'an dan al-Sunnah. Jika ajaran akhlak Islam yang berdasarkan al-Qur'an dan hadis bersifat universal, general, mutlak benar, dan berlaku sepanjang zaman, maka ajaran baik dan buruk yang berasal dari pancaindera (adat istiadat, budi pekerti dan budaya), dari akal pikiran (etika), dan hati nurani (moral) bersifat lokal, spesifik, nisbi dan bisa tidak berlaku. Ajaran baik buruk yang berupa etika yang berdasar pada akal sebagaimana yang berlaku di Barat misalnya, hanya berlaku di Barat saja, dan bisa dibatalkan. Namun demikian, ajaran baik dan buruk yang bersumber dari adat istiadat, budi pekerti, budaya, etika dan moral tetap diterima oleh akhlak Islam sebagai alat untuk menafsirkan dan melaksanakannya. Dengan demikian, di samping memilikisi sisi universal, akhlak Islam juga memiliki sisi lokal.

Sebagai contoh, akhlak Islam tentang menutup aurat adalah universal dan berlaku sepanjang zaman. Namun cara menutup aurat tersebut dapat menggunakan tradisi, budaya dan budi pekerti yang terdapat di setiap daerah, seperti Jawa, Sunda, Sumatera, dan sebagainya dapat digunakan untuk mempraktekkan cara menutup aurat sebagaimana yang dikehendaki al-Qur'an dan al- Hadis. Namun demikian, ada cara-cara model menutup aurat yang tidak diterima oleh Islam karena tidak sejalan dengan pesan ajarab menutup aurat yang dikendaki oleh Islam, yakni memelihara kesopanan, menghindari fithnah, memuliakan manusia, dan menghindari perbuatan maksiat, perkosaan dan kemorosotan akhlak.

Dengan demikian ajaran akhlak Islam bersifat militansi moderat. Yakni dari satu sisi terbuka dan akomodatif, namun dari sisi lain tetap militant, dalam arti tidak menerima perubahan.Dengan demikian akhlak Islam dapat menerima ajaran baik buruk yang berasal dari etika barat, ajaran moral dari tokoh spiritual, atau yang berasal dari peraturan perundangan yang dibuat pemerintah, dengan cara yang selektif melalui proses tabayyun(penjelasan), atau tatmim (penyempurnaan), sebagaimana yang dilakukan oleh Nabi Muhammad SAW yang menyatakan: bahwa ia diutus untuk menyempurnakan akhlak yang mulia. Kosakata menyempurnakan dalam hadis tersebut menggambarkan bahwa Nabi bukan hanya menghargai, melainkan menerima akhlak yang mulia yang pernah ada sebelumnya, yakni akhlak yang berasal dari etika Yunani, moralitas ajaran Sidharta Gautama, tradisi atau budaya China, India, dan Persia.

\section{Era Milenial Meniscayakan Integralisme Pendidikan Islam}

Karakter integralistik yang terdapat dalam pendidikan Islam dapat pula dijadikan alternative dalam menyiapkan manusia yang siap menghadapi era millennial. Sebagaimana telah dikemukakan di atas, bahwa era millennial antara lain ditandai oleh adanya generasi yang memiliki ciri aktif berkolaborasi, dan terbiasa berfikir out of the box. Generasi millennial tidak mau lagi dikurung oleh suatu pandangan 
tertentu, melainkan ia akan terus menjelajah, membuka diri, berinteraksi dengan semua aliran, pemikiran, pandangan, gagasan dan sebagainya dalam rangka memperoleh jawaban atas problema kehidupan kompleks yang dihadapinya.

Sikap esklusif, dan sectarian misalnya harus diganti dengan sikap inklusif dan toleran. Dalam upaya merespon kebutuhan generasi millennial yang salah satu wataknya yang demikian itu, maka pendidikan harus mengembangkan karakter integralistiknya dengan perspektif yang baru. Jika di zaman klasik umat Islam berkolaborasi atau mengintegrasikan pandangan al-Qur'an dengan llmu pengetahuan Yunani, India, China, Persia dan lainnya, maka di era Millennial integrase tersebut tidak memadai lagi. Integrasi di masa sekarang, integrasi harus dilakukan dengan ilmu pengetahuan modern dengan terlebih dahulu menghilangkan prinsip-prinsipnya yang tidak sejalan dengan prinsip Islam, seperti prinsipnya yang hanya mengakui yang rational dan empiris dengan ditambah dengan yang metafisis (al-ghaib). Selanjutya jika di masa klasik masing-masing bidang llmu, seperti kalam, filsafat dan tasawuf memberikan jawaban sendirisendiri atas berbagai persoalan umat, maka di masa sekarang ketiganya harus dipadukan.

Karakter integralisme pendidikan Islam ini lebih lanjut dapat dipahami dari gagasan dan pemikiran yang dikemukakan Armahedi Mazhar. Dalam hubungan ini ia mengatakan: Integralisme dapat digunakan sebagai filsafat yang menjembatani kebenaran-kebenaran diniyah yang tercantum dalam Kitab Suci Qur'an dengan kebenaran-kebenaraan ilmiah yang terbaca dalam Kitab Besar "alam semesta" seperti halnya filsafat tradisional Islam di zaman dahulu. Kita perlu berusaha mengganti filsafat Islam tradisional yang menghubungkan ilmu pengetahuan Yunani Helenistik dengan Qur'an Suci dengan suatu filsafat Islam modern yang menghubungkan ilmu pengetahuan modern dengan Qur'an Suci. Integralisme harus dikembangkan dengan tradisi kritis, generasi demi generasi, sehingga dapat menjadi apa yang disebut Alvin Toffler supra ideologi bagi peradaban Islam di masa depan. Integralisme melihat adanya kesatupaduan antara manusia-alamTuhan, atau Allah, alam-manusia.

Dengan integralisme ini akan memunculkan ilham-ilham Ilmiah di dalam pikiran para ilmuwan muslim sehingga mereka mampu menggali kandangankandungan makna dalam al-Qur'anul Karim untuk kemudian dikembangkan sebagai penemuan-penemuan ilmiah baru. Bukan sebaliknha seperti selama ini di mana ayat-ayat Qur'an dicari-cari untuk menjelaskan penemuan ilmiah atau teknologi baru kemudian digembar-gemborkan bahwa: "semuanya sudah ada di dalam Qur'an."

Selama sikap yang disebut belakangan ini yang diambil oleh para ilmuwan Muslim, mereka akan tetap menjadari tertawaan dunia ilmu pengetahuan modern, karena tidak bisa menyumbangkan apa-apa kecuali berteriak "semua sudah ada dalam al-Qur'an" untuk menutupi kompleks rendah diri mereka.

Karakter Integralistik pendidikan Islam yang dibutuhkan generasi millennial juga dapat dilakukan pada adanya integrasi pada paham Islam yang bercorak Ulum al-Din, al-Fikri dan Dirasat Islamiyah. Paham Islam Ulum al-Din yang cenderung menekankan sisi keagamaan, ritualitas, formalitas, sectarian, lokal, 
dangkal, parsial (sepotong-sepotong), provincial (terkotak-kotak; terbatas cara pandangnya); parochical (sempit); Sedangkan al-Fikr al-Islamiy atau Islamic Thought yang pendekatannya lebih historis, sistematis, utuh komprehensif, non sectarian, tidak provincial; dan Dirasat Islamiyah (Islamic Studies) yang selain masih merujuk pada kluster ilmu-ilmu keagamaan (Islam) yang paten standar baku dalam Ulum al- Din dan al-Fikr al-Islamy, ia juga ditopang dan diperkokoh oleh research (penelitian) lapangan, pendekatan historis-empiris yang obyektif tentang dinamika sosial, ketersambungan (continuity) dan perubahan(change), pola dan trend pergumulan sosial politk, ekonomi, budaya, pola-pola ketegangan, konflik, harmoni dan merekam pluralitas interpretasi makna oleh para pelaku di lapangan. ${ }^{7}$

Lebih jauh ditegaskan bahwa Islam dalam paham Ulum al-Din yang masih berada pada tahap tradisional, bahkan local dalam arti menegasikan sikap kritis yang kontekstual tentu akan menjadi jurang pemisah dengan masyarakat melenial. Sedangkan al-Fikri al-Islami berada pada tahap transisi ke arah pematangan munculnya Dirasaat Islamiyah yang bercorak kritis dan global. Sehubungan dengan ini, M. Amin Abdullah mengatakan: "Menurut hemat penulis, tetapi yang diperlukan untuk mengobati kecenderungan konservatisme dan eksklusifisme pendidikan agama di era modern" adalah bagaaimana mengelaas, menghubungkan dan mempertautkan hubungan yang kokoh antara ketiganya. Dirasat Islamiyah atau Islamic Studies yang bercorak critical dan dialogical perlu dikenalkan kepada anak-anak agar nilai-nilai dari keberagamaan yang autentik untuk menyangga kehidupan bersama dapat dipelihara dan dikembang-suburkan".

Melalui pendekatan integralisme nilai-nilai positif yang terdapat pada Ulum al-Din akan terlaksana, seperti berpegang teguh pada 'aqidah, kepatuhan dan ketekunan dalam menjalankan ritualitas kegamaan termasuk yang hukumnya sunnah, seperti shalat tahajjud, puasa Senin Kamis, membaca dan menghafal alQur'an, berzikir dan berdoa setelah shalat, kesalihan dalam sikap, silaturahmi dan sebagainya; nilai-nilai positif, pesan moral, dan spirit yang terdapat dalam ajaran Islam serta daya kritis dan analitis dari perspektif historis, sosiologis dan lainnya. Pemahaman yang demikian akan menimbulkan kebanggaan pada Islam; serta pesan-pesan universalitas, kemanusiaan, keadilan, kedamaian, kebersaamaan dan sebagainya sebagaimana terdapat pada paham Islam Dirasat Islamiyah (Islamic Studies) yang menumbuhkan dimensi sikap menjunjung tinggi pesan-pesan kemanusiaan yang universal dapat ditumbuhkan.

Dalam konteks era millennial seperti sekarang ini, cara yang ditempuh pendidikan Islam bukanlah mempertentangkan antara paham Islam model Ulum al-Din yang bercorak lokal, yang bercorak global, dan bukan pula dengan cara memilih yang satu dan meninggalkan yang lainnya; melainkan dengan memadukan, mengkolaborasi dan mengintegrasikannya, mengingat pada masingmasing paham Islam tersebut terdapat nilai-nilai positif yang dibutuhkan generasi milennial.

${ }^{7}$ M. Amin Abdullah, Islamic Studies di Perguruan Tinggi: Pendekatan Integratif-Interkonektif, (Yogyakarta: Pustaka Pelajar, 2006), hlm. 277-278. 


\section{Entrepreneurship dan Pendidikan Islam}

Saat ini di Indonesia memiliki cukup banyak pondok pesantren. Selain ada yang bercorak tradisional (salafiyah) yang hanya menyelengarakan pendidikan ilmu agama Islam; ada yang bercorak modern (khalafiyah) yang di samping menyelenggarakan pendidikan ilmu agama, juga menyelenggarakan pendidikan umum, mulai tingkat Taman Kanak-kanak, dasar, menengah hingga perguruan tinggi dengan berbagai bentuknya: politeknik, akademi, sekolah tinggi, institute maupun universitas. Di antara Lembaga-lembaga pendidikan Islam tersebut ada yang tergolong maju, terkemuka dan mendapat pengakuan yang luas baik nasional maupun internasional. Pondok pesantren Darussalam, Gontor Ponorogo, Jawa Tengah; Pondok Pesantren Darul Umum di Jombang, jawa Timur, Pondok Pesantren Tebu Ireng, Jombang Jawa Timur, Pondok Pesantren Tambak Beras, Pondok Pesantren Sunan Drajat, Paciran, Lamongan, Jawa Timur; dan Pondok Pesantren Modern lainnya yang baru tumbuh dan berkembang di berbagai daerah di Indonesia yang jumlahnya belum dapat diketahui dengan pasti. Hal yang menarik dari pertumbuhan dan perkembangan pendidikan Islam termasuk yang berada di Pondok Pesantren yang tergolong modern tersebut statusnya swasta. Kemajuan, nama besar, kepercayaan masyarakat, jenis dan jenjang program pendidikan yang beragam, area kampus yang luas, infra-structure, sarana, prasarana, fasilitas yang lengkap dan modern, manajemen pengelolaan yang professional, kondisi keuangan yang sehat dan kuat, kemasan, branded dan pemasaran yang modern, mereka capai dengan usaha dan kerja keras yang tidak mengenal Lelah, serta keuletan dan keberanian dalam mengambil keputusan dengan resiko yang diperhitungkan. Adanya kemajuan yang dicapai Lembaga pendidikan Islam tersebut menujukan bahwa di dalam Lembaga pendidikan tersebut adalah kegiatan entrepreneurship (kewirausaha atau wiraswasta). Wiraswasta terdiri dari tiga kata:wira,swa dan sta, masing-masing berarti: wira adalah manusia unggul, teladan, berbudi luhur, berjiwa besar, pahlawan, pendekar kemajuan, dan memiliki keagungan watak, swa artinya sendiri; dan sta artinya berdiri. Dengan demikian secara etimologi, wiraswasta berari keberanian, keutamaan seta keperkasaan dalam memenuhi kebutuhan serta memecahkan permasalahan hidup dengan kekuatan yang ada pada diri sendiri. ${ }^{8}$

Wirausaha berbeda dengan pedagang atau saudagar yang berasal dari kata sau yang berarti seribu, dan dagar yang artinya akal. Jadi saudagar berarti seribu akal. ${ }^{9}$ Seorang pedagang terbatas pada kegiatan membeli dan menjual produk yang dibuat oleh orang lain, dengan tujuan terbatas pada mencari keuntungan. Sedangkan seorang wirausaha harus ada inisiatif, kreatifitas, menciptakan hal baru, menyediakan pekerjaan bagi orang lain, menanggung resiko, menciptakan hal-hal baru, memulai dari nol, kerja keras dan tidak kenal lelah, motivasi dan

8 Alma, Buchari., Kewirausahaan untuk Mahasiswa dan Umum (Bandung: Alfabeta, 2011), hlm. 17.

9 Taufik Rashid (Peny.) Bunga Rampai Wiraswasta: Orientasi konsepsi dan Ikrar. Bandung: Tugas Wiraswasta,1981), hlm. 4; lihat juga Alma, Buchari, Kewirausahaan., hlm. 17. 
komitmen yang tinggi, jujur, keterbukaan, kreatif, kritis, produktif, dan pengambil resiko. $^{10}$

\section{Kesimpulan}

Dengan memperhatikan catatan tersebut di atas, dapat diketahui bahwa adanya kemajuan yang terdapat pendidikan Islam sebagaimana yang terjadi pada Pondok Pesantren, menunjukkan bahwa Pondok Pesantren tidak hanya telah memiliki wawasan, pemahaman dan penghayatan terhadap nilai-nilai dan sikap kewirausahaan. Akan tetapi juga telah mempraktekkan sikap yang dimiliki para pendiri dan pengelola lembaga pendidikan termasuk para kiai adalah para entrepreneur yang memiliki wawasan, pemahaman, penghayatan dan pengamalan nilai-nilai kewirausahaan (inisiatif, kreatifitas, menciptakan hal baru, menyediakan pekerjaan bagi orang lain, menanggung resiko, menciptakan hal-hal baru, memulai dari nol, kerja keras dan tidak kenal lelah, motivasi dan komitmen yang tinggi, jujur, keterbukaan, kreatif, kritis, produktif, dan pengambil resiko). Sikap kewirausahaan ini sejalan dengan sikap generasi millennial sebagaimana tersebut di atas, yakni dinamis, inovatif, kreatif, dan berani keluar dari kebiasaan lama (out of the box).

10 Nursito, S. \& Nugroho, A. J. Analisis Pengaruh Interaksi Pengetahuan dan Efikasi Diri Terhadap Intensi Kewirausahaan. Jurnal Kiat Bisnis, 5 (2), tahun 2013, hlm. 149-158. 


\section{Bibliografi}

Alquran Terjemah, Jakarta: Departemen Agama RI, 2006.

Abuddin Nata, Pendidikan Islam di Era Milenial, Conciencia, Vol. 18, No. 1, tahun 2018.

Al-Abrasyi, Mohd. Athiyah, Dasar-dasar Pokok Pendidikan Islam, terj. A. Bustami Gani, Jakarta: Bulan Bintang, 1970.

Alma, Buchari., Kewirausahaan untuk Mahasiswa dan Umum, Bandung: Alfabeta, 2011.

Noory Okthariza, Generasi Milenial, Toleransi, dan Globalisasi, Kompas, 28 Desember 2017.

M. Amin Abdullah, Islamic Studies di Perguruan Tinggi: Pendekatan IntegratifInterkonektif, Yogyakarta: Pustaka Pelajar, 2006.

Nursito, S. \& Nugroho, A. J. Analisis Pengaruh Interaksi Pengetahuan dan Efikasi Diri Terhadap Intensi Kewirausahaan. Jurnal Kiat Bisnis, 5 (2), tahun 2013 hlm. 149-158.

Taufik Rashid (Peny.) Bunga Rampai Wiraswasta: Orientasi konsepsi dan Ikrar. Bandung: Tugas Wiraswasta,1981.

William F. O'neil, Ideologi-ideologi Pendidikan, penterj. Omi Intan Naomi, Yogyakarta: Pustaka Pelajar, 2008. 